\title{
Selection and Validation of Reference Genes for the qRT-PCR Assays of Populus ussuriensis Gene Expression under Abiotic Stresses and Related ABA Treatment
}

\author{
Ming Wei ${ }^{\dagger}$, Yingxi Chen ${ }^{\dagger}$, Mengqiu Zhang, Jingli Yang, Han Lu, Xin Zhang and Chenghao Li ${ }^{*}$ \\ State Key Laboratory of Tree Genetics and Breeding, Northeast Forestry University, Harbin 150040, China; \\ weiming920312@163.com (M.W.); 18743585595@163.com (Y.C.); 18814568399@163.com (M.Z.); \\ yifan85831647@163.com (J.Y.); virginia_su@163.com (H.L.); 13199385849@163.com (X.Z.) \\ * Correspondence: chli@nefu.edu.cn; Tel.: +86-0451-8219-1556 \\ † These authors contributed equally to this work.
}

Received: 6 April 2020; Accepted: 21 April 2020; Published: 23 April 2020

\begin{abstract}
Populus ussuriensis Kom. is one of the most important tree species for forest renewal in the eastern mountainous areas of Northeast China due to its fast growth, high yield, and significant commercial and ecological value. The selection of optimal reference genes for the normalization of qRT-PCR data is essential for the analysis of relative gene expression. In this study, fourteen genes were selected and assessed for their expression stability during abiotic stress (drought, high salinity, and cold stress) and after the treatment with the drought-related hormone ABA. Three algorithms were used, geNorm, NormFinder, and BestKeeper, and a comprehensive ranking of candidate reference genes was produced based on their output. The most appropriate reference genes were $U B Q 10$ and RPL24 for drought and ABA treatment, $U B Q 10$ and TUB3 for cold stress, and $U B Q 10$ and $60 S r R N A$ for high salinity. Overall, $U B Q 10$ was the most stable reference gene for use as an internal control, whereas $P P 2 A$ was the least stable. The expression of two target genes (P5CS2 and GI) was used to further verify that the selected reference genes were suitable for gene expression normalization. This work comprehensively assesses the stability of reference genes in Populus ussuriensis and identifies suitable reference genes for normalization during qRT-PCR analysis.
\end{abstract}

Keywords: Populus ussuriensis; gene expression; qRT-PCR; abiotic stress; abscisic acid

\section{Introduction}

Gene expression analysis is the basis of modern molecular biology and is widely used in genetic and developmental studies. Gene expression can be analyzed by several RNA quantification methods, including Northern blots, RNase protection assays, semi-quantitative reverse-transcription PCR, and quantitative real-time PCR (qRT-PCR), all of which rely on normalization procedures to quantitatively compare multiple samples [1]. qRT-PCR has become a common technique for gene expression analysis because of its rapidity, high sensitivity, and quantitative accuracy [2,3]. Moreover, qRT-PCR is regarded as the only effective way to measure the expression of genes with low mRNA copy number [4]. However, due to differences in RNA quality and quantity, in the efficiency of DNA synthesis, in PCR amplification, in pipetted volumes, and especially, in the activity of tissues and cells, qRT-PCR results can be severely biased [5]. A set of MIQE (Minimum Information for Publication of Quantitative Real-Time PCR Experiments) guidelines aimed at improving the reliability and repeatability of research using qRT-PCR, has been published, which refers to a suitable reference gene (RG) for normalization as being essential for obtaining reliable results [6]. RGs whose expression 
does not change among tissues or in response to experimental conditions are required to serve as internal controls and avoid bias in qRT-PCR [7]. However, the ideal RG that is stably expressed under all experimental conditions is almost non-existent [8,9]. Therefore, identifying multiple RGs that are stable under specific experimental conditions and using them to normalize target gene expression is essential for obtaining reliable qRT-PCR results.

RGs are generally a set of highly-conserved housekeeping genes (HKGs) whose expression is required to maintain baseline cellular function; they are typically expressed at relatively constant levels in different tissues [10]. Commonly-used housekeeping genes, including ACT7 (actin 7), $\beta$-TUB ( $\beta$-tubulin), 18S rRNA (18S ribosomal RNA), EIF4A (eukaryotic initiation factor 4AIII), UBQ (polyubiquitin), and GAPDH (glyceraldehyde-3-phosphate dehydrogenase), are widely used for gene expression analysis under different experimental conditions in diverse plant species. In previous studies in rice, $18 \mathrm{~S}$ rRNA and $28 \mathrm{~S}$ rRNA exhibited the most stable expression when plants were grown under various environmental conditions, including osmotic stress, hormone treatment, and different temperatures. UBQ5 and EF1- $\alpha$ were the most stable in various tissues and developmental stages, including 7-day-old light- and dark-grown seedlings, shoots and roots, mature leaves and seeds, and pre-pollinated or post-fertilized flowers [9]. 18S rRNA expression was the most stable in etiolated rice seedlings after several UV irradiation treatments [11]. Xu et al. [12] reported that EF1 $\alpha$ and $18 \mathrm{~S}$ rRNA were the most suitable RGs during adventitious root development, whereas ACT was the most unstable gene across multiple developmental stages in hybrid poplar. In soybeans, the expression levels of ELF1B and CYP2 were stable, and these genes could be used as internal controls to normalize gene expression in different tissues [13]. In these studies, the expression of HKGs differed among organ types, developmental stages, and environmental conditions. Therefore, it is necessary to re-screen HKGs to determine which are suitable for specific experimental conditions.

Populus ussuriensis Kom. is one of the most important tree species for forest renewal in the eastern mountainous areas of Northeast China due to its fast growth and high yield. It is an excellent raw material for the production of paper and glued sheets because of its soft wood and high toughness, and it has significant commercial and ecological value [14,15]. Our previous work showed that the expression of genes encoding calmodulin-binding transcription activators differed between P. ussuriensis and Populus trichocarpa under cold stress, probably due to the differences in cold tolerance between the two species [15]. Ectopic expression of LbDREB from Limonium bicolor in P. ussuriensis has been shown to improve its drought resistance [16]. PuHSFA4a overexpression in P. ussuriensis increased tolerance to excess $\mathrm{Zn}$ by directly regulating PuGSTU17 to remove reactive oxygen species from roots and by regulating PuPLA2 to promote root growth [17]. Although several genes and their expression characteristics have been studied in P. ussuriensis, a review of the literature suggests that the traditional housekeeping gene Actin is the only RG that has been used in poplar (Populus spp.) [18-20]. Therefore, the identification of additional RGs in P. ussuriensis that are more stable under various stresses is essential for obtaining reliable qRT-PCR results.

Here, we report an experiment designed to select suitable RGs for qRT-PCR assays in P. ussuriensis under various abiotic stresses (drought, high salinity, and cold stress) and following treatment with the drought-related hormone ABA. Fourteen candidate RGs were selected from a local P. ussuriensis transcriptome database for the evaluation of expression stability with the stem-loop qRT-PCR method. Their expression stability was evaluated using three software programs: geNorm [21], NormFinder [22], and BestKeeper [23]. We also screened out two target genes from previous studies, delta 1-pyrroline-5-carboxylate synthetase 2 (P5CS2) and GIGANTEA (GI), and used them to assess the suitability of selected RGs. Our results will aid future studies of $P$. ussuriensis gene expression under abiotic stress and phytohormone treatment. 


\section{Materials and Methods}

\subsection{Plant Materials and Stress Treatments}

Populus ussuriensis clone Donglin plants were grown in vitro on half-strength Murashige and Skoog (1/2 MS) medium (Phytotech) with $0.6 \%(\mathrm{w} / \mathrm{v})$ agar and 2\% (w/v) sucrose [15]. Plants were cultured in $250 \mathrm{~mL}$ plastic containers that held $100 \mathrm{~mL}$ of medium and were housed in a growth chamber at $25{ }^{\circ} \mathrm{C}$ with a $16 \mathrm{~h}$ light/8 h dark photoperiod and a light intensity of $46 \mu \mathrm{mol} \mathrm{m}^{-2} \mathrm{~s}^{-1}$. For stress treatments, 5-leaf-stage in vitro plants were transferred to 1/2 MS medium supplemented with 7\% PEG 6000 (drought), $150 \mathrm{mM} \mathrm{NaCl}$ (high salinity), or $100 \mu \mathrm{M}$ abscisic acid (ABA) medium that had been precooled at $4{ }^{\circ} \mathrm{C}$ (cold stress). All media were adjusted to $\mathrm{pH} 5.8$ and sterilized by autoclaving at $121^{\circ} \mathrm{C}$ for $20 \mathrm{~min}$. Leaf and root tissues from each treatment were independently collected at six time points $(0 \mathrm{~h}, 6 \mathrm{~h}, 12 \mathrm{~h}, 24 \mathrm{~h}, 48 \mathrm{~h}$, and $72 \mathrm{~h})$. Non-treated plants were used as controls. All samples were immediately frozen in liquid nitrogen and stored at $-80^{\circ} \mathrm{C}$ for analysis. There were three biological replicates of each experimental condition.

\subsection{Total RNA Extraction and cDNA Synthesis}

RNA extraction was carried out according to the MIQE guidelines to ensure the reliability of the results [6]. Total RNA from each sample (approximately $100 \mathrm{mg}$ of leaf or root tissue) was isolated using the CTAB (cetyltrimethylammonium bromide) method [24] and treated with DNaseI to remove genomic DNA contamination. The concentration and quality of each RNA sample were measured spectrophotometrically using the OD260/OD280 and OD260/OD230 absorption ratios, and all RNA samples were verified by $1 \%(w / v)$ agarose gel electrophoresis. cDNA was synthesized using the HiScript II Q RT SuperMix for qPCR (+gDNA wiper) (Vazyme, Nanjing, China) in a $20 \mu \mathrm{L}$ reaction system according to the manufacturer's instructions. The cDNA was diluted 50-fold with $\mathrm{ddH}_{2} \mathrm{O}$ and used as the template for PCR amplification.

\subsection{Candidate Reference Gene Selection and PCR Primer Design}

Fourteen candidate genes from a local P. ussuriensis transcriptome database were selected for assessment of their stability and suitability as RGs for the normalization of qRT-PCR data under various experimental treatments. Primers were designed based on the cDNA sequences of the candidate reference genes using Primer Premier 6 software (http://www.premierbiosoft.com/) with the following criteria: primer length 17-25 bp (optimum 20), product size 75-300 bp, melting temperature 50-65 ${ }^{\circ} \mathrm{C}$ (optimum $60{ }^{\circ} \mathrm{C}$ ), and GC content $40 \%-60 \%$ (optimum $50 \%$ ). The specificity of all selected primer pairs was assessed by PCR using the cDNA of control groups at $0 \mathrm{~h}$ as the template, and gene fragments were visualized following $2.0 \%(\mathrm{w} / \mathrm{v})$ agarose gel electrophoresis to ensure reliability. All primers mentioned above are listed in Table 1.

\section{4. $q R T-P C R$}

TransStart ${ }^{\circledR}$ Top Green qPCR SuperMix (TransGen, Beijing, China) was used to perform qRT-PCR in 96-well optical reaction plates (Applied Biosystems, Foster City, CA, USA). Reactions were prepared in $20 \mu \mathrm{L}$ volumes containing: $10 \mu \mathrm{L}$ of $2 \times$ TransStart $^{\circledR}$ Top Green qPCR SuperMix, $7.2 \mu \mathrm{L}$ of ddH ${ }_{2} \mathrm{O}$, $2 \mu \mathrm{L}$ of 50 -fold diluted cDNA, and $0.4 \mu \mathrm{L}$ of each specific primer, prepared to a final concentration of $10 \mu \mathrm{M}$. The qRT-PCR program consisted of an initial step at $94{ }^{\circ} \mathrm{C}$ for $30 \mathrm{~s}$, followed by 40 denaturation cycles at $94^{\circ} \mathrm{C}$ for $5 \mathrm{~s}$ and primer annealing at $60^{\circ} \mathrm{C}$ for $30 \mathrm{~s}$. Next, melting curves ranging from $60{ }^{\circ} \mathrm{C}$ to $95{ }^{\circ} \mathrm{C}$ with an increment of $0.2{ }^{\circ} \mathrm{C}$ were recorded in each reaction to check the specificity of the amplicons. Three technical replicates were analyzed for each biological sample. The threshold cycle (Ct) was automatically measured. A total of 48 cDNA samples from six time points in the control groups were used to determine the mean amplification efficiency $(E)$ of each primer pair using the LinRegPCR program. The relative expression levels of two target genes (PuP5CS2 and PuGI) were calculated with the equation $2^{-\Delta \Delta C t}$ under abiotic stress and ABA treatment, respectively [25]. 
Table 1. Description of candidate reference genes (RGs) and target genes, primer sequences, product sizes, and amplicon characteristics.

\begin{tabular}{|c|c|c|c|c|c|c|}
\hline Gene Symbol & $\begin{array}{c}\text { Accession } \\
\text { Number }\end{array}$ & Gene Name & Primer Sequence $\left(5^{\prime}-3^{\prime}\right)$ & $\begin{array}{l}\text { Amplicon } \\
\text { Size (bp) }\end{array}$ & $\begin{array}{c}\text { Amplification } \\
\text { Efficiency }(E)\end{array}$ & $\begin{array}{c}\text { Correlation } \\
\text { Coefficient }\left(R^{2}\right) \\
\end{array}$ \\
\hline \multicolumn{7}{|c|}{ Reference Genes } \\
\hline ACT7 & MN872586 & Actin7 & $\begin{array}{l}\text { ATGGAACTGGAATGGTGAAGGCTGG } \\
\text { CCGTGCTCAATGGGGTATTTCAAGGTC }\end{array}$ & 187 & 1.85 & 0.9971 \\
\hline TUA2 & MN872587 & Tubin alpha 2 & $\begin{array}{l}\text { TTCAAGTCGGAAATGCCTGCTGGGAAC } \\
\text { GTTGGCAGCATCTTCCTTGCCGC }\end{array}$ & 263 & 1.90 & 0.9968 \\
\hline TUB3 & MN872588 & Tubulin beta chain 3 & $\begin{array}{l}\text { ATGAGGGAAATCCTTCACATTCAAGGAGG } \\
\text { CCAGGCTCAAGATCCATAAGCACAGC }\end{array}$ & 212 & 1.99 & 0.9927 \\
\hline GAPDH & MN872589 & $\begin{array}{l}\text { Glyceraldehyde 3-phosphate } \\
\text { dehydrogenase }\end{array}$ & $\begin{array}{l}\text { GGAAGCACGGAGATATCAA } \\
\text { ACCACCCTTCAAATGAGCA }\end{array}$ & 187 & 2.08 & 0.9936 \\
\hline$U B Q 10$ & MN872590 & Polyubiquitin & $\begin{array}{c}\text { GGAGTCAACCCTTCACTTGGTGC } \\
\text { GAGGACAAGGTGAAGGGTGGACTCC }\end{array}$ & 253 & 1.97 & 0.9925 \\
\hline$E F 1-\alpha$ & MN872591 & Elongation factor 1-alpha & $\begin{array}{l}\text { CACTGGTCACTTGATCTACAAGCTTG } \\
\text { TGACAGTGCAGTAGTACCTGG }\end{array}$ & 200 & 1.82 & 0.998 \\
\hline$S A N D$ & MN872592 & SAND family & $\begin{array}{l}\text { ATGTCCTCATCCGATTCCAACTCCTC } \\
\text { CACGACACTCCTGACGAGGCC }\end{array}$ & 240 & 2.00 & 0.9963 \\
\hline $60 S$ rRNA & MN872593 & $\begin{array}{l}\text { 60S acidic ribosomal protein } \\
\text { P0-A }\end{array}$ & $\begin{array}{l}\text { CTTCAGCCCTGAGGTGCTGGACC } \\
\text { GCACCCCCAGAAGCAGCAGC }\end{array}$ & 276 & 2.05 & 0.9959 \\
\hline$P P 2 A$ & MN872594 & Protein phosphatase & $\begin{array}{l}\text { CAGCTAAGGTTAAACTCAATCCGTAGAC } \\
\text { CCTCGACAGTGCAAAGAGTCTCC }\end{array}$ & 226 & 1.98 & 0.9935 \\
\hline CYP2 & MN872595 & Cyclophilin & $\begin{array}{l}\text { ATTGGCAAGATGAAAGCAGGTAGGATTG } \\
\text { CTTTGCGCCATAGATTGATTCTCCTC }\end{array}$ & 234 & 1.99 & 0.9986 \\
\hline F-box & MN872596 & F-box family protein & $\begin{array}{l}\text { GGGGCTGGAATCAGTGGGAG } \\
\text { GCAGAAAGATCAAGATCTTGACGGC }\end{array}$ & 162 & 2.01 & 0.9918 \\
\hline RPL24 & MN872597 & $60 \mathrm{~S}$ ribosomal protein L24 & $\begin{array}{l}\text { CCTCGACTGTATACCCGGGGC } \\
\text { GATTCCTATCATATCTCTCAGGCC }\end{array}$ & 225 & 1.99 & 0.9996 \\
\hline RPL25 & MN872598 & $\begin{array}{l}\text { Large subunit ribosomal } \\
\text { protein L23Ae }\end{array}$ & $\begin{array}{l}\text { GGCTGATGCAAAGACACAGGCAC } \\
\text { GGTTCCTTTCCTTCTTCAATGTCCTGG }\end{array}$ & 134 & 1.94 & 0.9985 \\
\hline$U B C$ & MN872599 & Ubiquitin-protein ligase & $\begin{array}{l}\text { GTCAACCCCAGCCAGGAAGAGG } \\
\text { CTTAAACGTCCCTCCATCCCATGG }\end{array}$ & 160 & 1.99 & 0.9974 \\
\hline P5CS2 & MN872600 & $\begin{array}{c}\text { Delta1-pyrroline-5-carboxylate } \\
\text { synthase } 1\end{array}$ & $\begin{array}{l}\text { Target Genes } \\
\text { CACGGATCCTTCTCGTGGTT } \\
\text { TTTTTGGAGATCGGCGAAGC }\end{array}$ & 247 & 1.99 & 0.9991 \\
\hline GI & MN872601 & GIGANTEA protein & $\begin{array}{l}\text { GCAGCCCTCCATTTGCTTCT } \\
\text { TTGCCATCACTGCTGCTTCT }\end{array}$ & 178 & 1.97 & 0.9942 \\
\hline
\end{tabular}




\subsection{Statistical Analysis to Determine Expression Stability with geNorm, NormFinder, and BestKeeper}

To analyze the expression stability of 14 candidate RGs, the cycle thresholds (Cts) from different tissues under different stresses and treatments were analyzed using box plots and three different algorithms of the statistical tools geNorm [21], NormFinder [22], and BestKeeper [23]. The geNorm tool calculates the average expression stability value ( $M$ value) of RGs based on the average pairwise variation $(V)$ value. With 1.5 as the threshold, a lower $M$ value corresponds to a more stable gene. The $V$ value calculated by geNorm determines the optimal number of RGs required to accurately normalize the data and is based on a threshold value of $V n+1<0.15$. The NormFinder tool analyzes the stability of candidate RG expression based on the results of intra- and inter-group variation analysis and automatically ranks the genes according to their stability value (SV) [22]. A lower SV corresponds to higher stability. BestKeeper assesses the stability of RGs based on the standard deviation (SD) and coefficient of variation (CV) of the $\mathrm{Ct}$ values. An RG with an SD less than 1 is considered to be stably expressed. The CV decreases with the SD, indicating that the RG is more stable $[23,26]$.

\subsection{Validation of Candidate Reference Genes}

To assess the accuracy of the expression stability of candidate RGs, the geometric means of the ranking results from geNorm, NormFinder, and BestKeeper for each stress or treatment were used to calculate a comprehensive ranking of candidate genes. The lower the comprehensive ranking, the better the stability of gene expression. Finally, the two best RGs for each experimental condition were used to normalize the expression of two target genes, PuP5CS2 and PuGI, under that condition.

\section{Results}

\subsection{Selection, Amplification Efficiency, and Ct Value Range of Candidate Reference Genes}

We compared RGs used previously in other plant species, such as Arabidopsis thaliana, with a local P. ussuriensis transcriptome database using a local Blast search in Bioedit. Fourteen candidate RGs were selected for use in the gene normalization studies (Table 1). To evaluate the amplification efficiency of primer pairs, $\mathrm{PCR}$ amplification specificities were assessed using $2.0 \%$ agarose gel electrophoresis (Figure S1), melting curves (Figure S2), and direct sequencing. The results showed that we obtained specific target fragments of the expected lengths and sequences. The qRT-PCR amplification efficiency $(E)$ and correlation coefficient $\left(R^{2}\right)$ were obtained from the slope of the calibration curves (Table 1 ). For the 14 candidate RGs and two target genes, the $E$ values ranged from 1.85 to 2.08 and the $R^{2}$ values ranged from 0.9918 to 0.9996 (Table 1 ). The results showed that all 16 pairs of primers met the requirements for use in qRT-PCR experiments.

\subsection{Expression Profiles of Candidate Reference Genes under Abiotic Stresses and Hormone Treatment}

The $\mathrm{Ct}$ value is the cycle number at which the reaction curve intersects the threshold line; it indicates the number of cycles required to detect a real signal from the sample. High abundance cDNA samples reach this threshold at a lower $\mathrm{Ct}$ value during PCR amplification, indicating a higher gene expression level [27]. The transcript abundances of $14 \mathrm{RGs}$ were determined based on Ct values from the qRT-PCR analysis of 48 samples, including six time points for roots and leaves under four treatment conditions (drought, high salinity, cold stress, and ABA treatment). Mean Ct values ranged from 15.15 (UBQ10) to 29.86 (SAND) (Figure 1). Under all stresses and treatments, UBQ10 had the highest expression and $S A N D$ had the lowest expression. The coefficient of variation $(C V)$ is related to the degree of fluctuation in Ct values. The highest and lowest CVs were $7.25 \%$ (TUA2) and $0.85 \%$ (UBQ10) under drought, 9.4\% (TUA2) and 0.94\% (F-box) under ABA treatment, 13.30\% (UBC) and $1.80 \%$ (UBQ10) under cold stress, and $11.07 \%$ (RPL25) and 1.18\% (SAND) under high salinity (Figure 1). The average CVs of the candidate RGs were ranked as $U B Q 10<C Y P 2<S A N D<G A P D H<F$-box $<$ RPL24 $<60 S$ rRNA $<$ PP2A $<U B C<$ TUB3 $<$ ACT7 $<$ RPL25 $<$ EF1- $\alpha<$ TUA2. 
Forests 2020, 11, 476

6 of 18
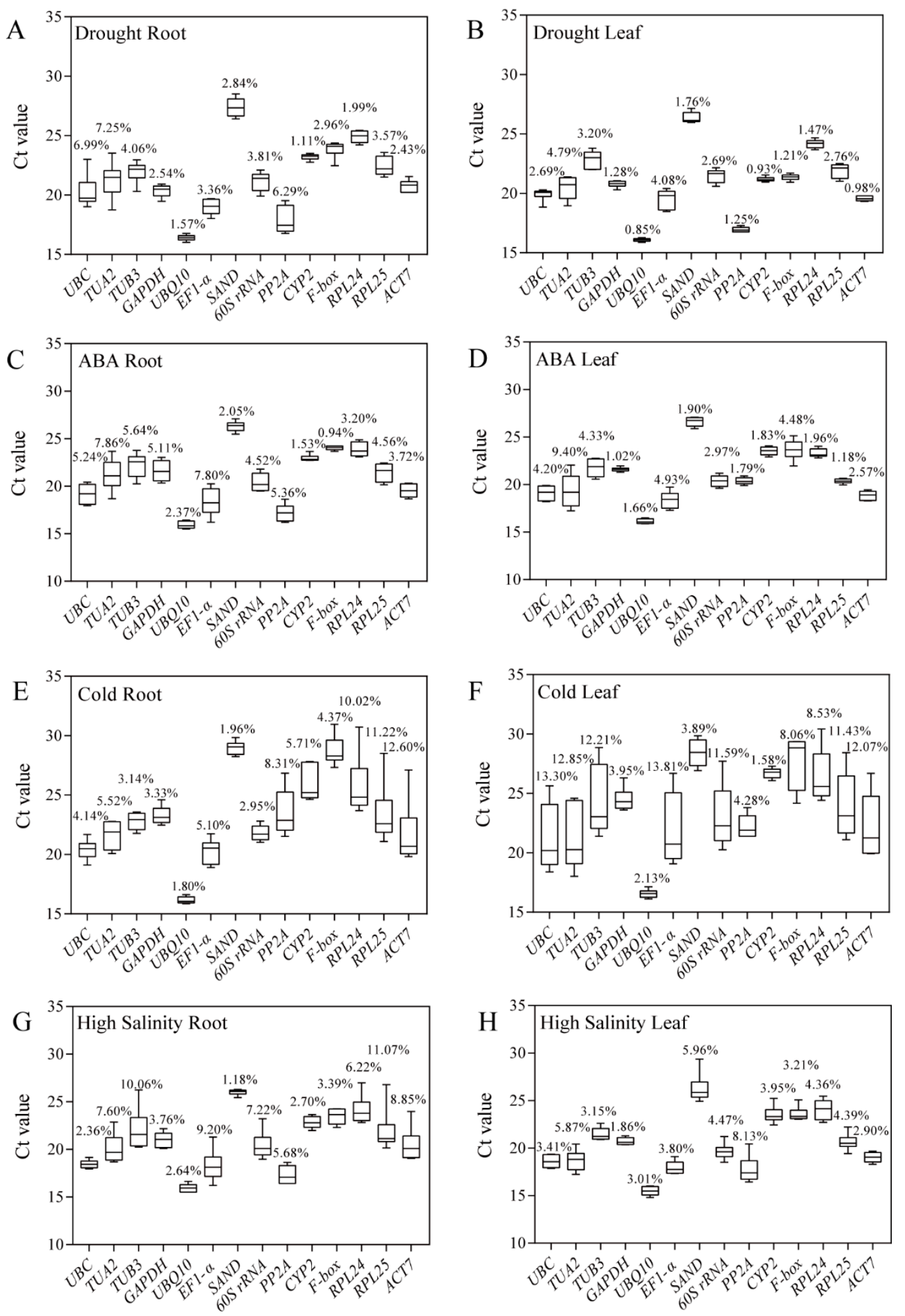

Figure 1. Threshold cycle $(\mathrm{Ct})$ values of fourteen candidate reference genes in roots and leaves under various stresses and ABA treatment. Boxplot of $\mathrm{Ct}$ values of fourteen candidate reference genes from qRT-PCR analysis of root and leaf tissues. (A,B) Drought stress; (C,D) ABA treatment; (E,F) cold stress; and $(\mathbf{G}, \mathbf{H})$ high salinity stress. For each reference gene, the line inside the box is the median. The top and bottom lines of the box are the first and third quartiles, respectively. The values on top of box represent the coefficient of variation $(\mathrm{CV})$ values. 


\subsection{Expression Stability of Candidate Reference Genes under Abiotic Stress and Hormone Treatment}

To identify the most suitable RGs for gene expression analysis under drought, high salinity, cold stress, and ABA treatment in P. ussuriensis, the expression stability of candidate RGs was evaluated by three different algorithms in geNorm, NormFinder, and BestKeeper.

\subsection{1. geNorm Analysis}

The geNorm tool calculates an RG stability value ( $M$ value) based on the average pairwise variation $V$ value [21]. The more stable the gene, the lower the $M$ value, and vice versa. As shown in Figure 2 and Table 2, all 14 RGs showed average $M$ values less than 1.5 under drought, high salinity, cold stress, and ABA treatment. UBQ10 and ACT7 $(M=0.300)$ were the most stable RGs under drought stress. RPL24 and ACT7 were the most stable RGs under ABA treatment $(M=0.22)$. F-box was the least stable RG under drought stress and ABA treatment, with $M$ values of 0.88 and 0.94 , respectively. Under cold stress, the stability of $F$-box was again the lowest $(M=1.88)$, consistent with the results of the drought and ABA treatment. TUB3 and EF1- $\alpha$ were the most stable RGs with $M$ values of 0.36 . Under high salinity stress, TUA2 and RPL24 were the most stable RGs with $M$ values of 0.54 , and $P P 2 A$ was the least stable RG with an $M$ value of 1.28. For all conditions except cold stress, ACT7 and RPL24 were among the top three stable RGs. By contrast, $F$-box was the least stable RG in all conditions except high salinity, in which $P P 2 A$ was the least stable RG.
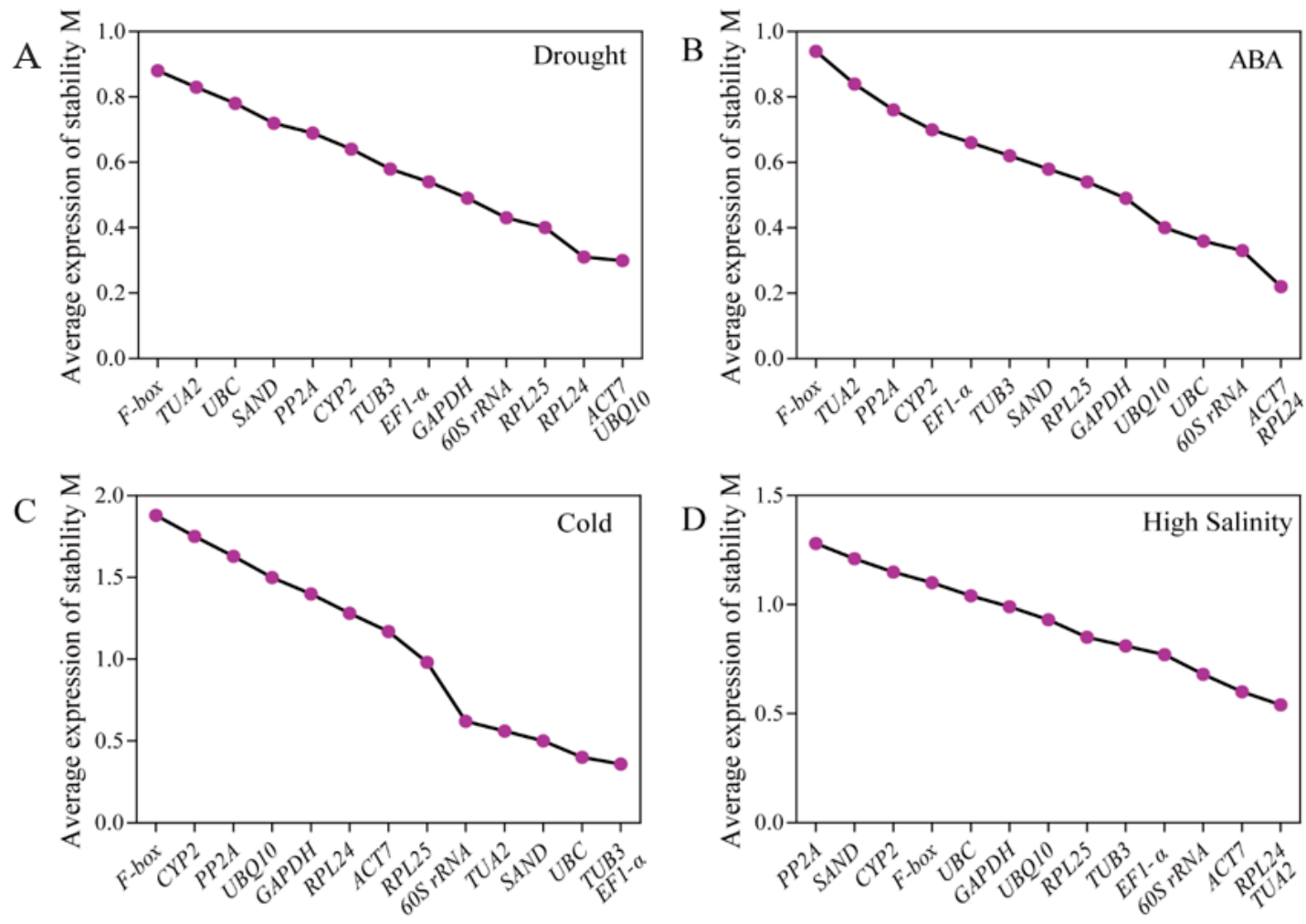

Figure 2. Average expression stability value $(\mathrm{M})$ and ranking of the fourteen RGs across all stresses and ABA treatment calculated using geNorm. (A) Drought stress, (B) ABA treatment, (C) cold stress, and (D) high salinity stress. The least stable genes are listed on the left, and the most stable genes are listed on the right.

Sometimes a single RG does not meet the stability requirements for use in normalization, and two or more RGs are therefore needed to reduce error and obtain more accurate results [28]. geNorm can determine the optimal number of candidate RGs based on the calculation of pairwise variation $(\mathrm{Vn} / \mathrm{Vn}+1)$. The program suggests a threshold of 0.15 as a standard for selecting the best pairwise variation value ( $V$ value) for normalization. There is no need to add more candidate $R G$ s if the $V$ 
value is lower than 0.15 . As shown in Figure 3, the value of V5/V6 among 14 candidate RGs under salt stress was 0.125 , which is smaller than 0.15 , suggesting that the most suitable RG combination contained four genes, namely $60 S r R N A, A C T 7, T U A 2$, and RPL24. Similarly, the most appropriate RG combinations under drought, $\mathrm{ABA}$, and cold stress were ACT7 and UBQ10, ACT7 and RPL24, and TUB3 and EF1- $\alpha$, respectively.

Table 2. Expression stability of candidate reference genes calculated by geNorm.

\begin{tabular}{|c|c|c|c|c|c|c|c|c|}
\hline \multirow{2}{*}{ Rank } & \multicolumn{2}{|c|}{ Drought } & \multicolumn{2}{|l|}{ ABA } & \multicolumn{2}{|l|}{ Cold } & \multicolumn{2}{|c|}{ High Salinity } \\
\hline & Gene Name & $M$ & Gene Name & $M$ & Gene Name & $M$ & Gene Name & $M$ \\
\hline 1 & UBQ10 & 0.30 & RPL24 & 0.22 & TUB3 & 0.36 & TUA2 & 0.54 \\
\hline 2 & $A \widetilde{C T 7}$ & 0.30 & ACT7 & 0.22 & $E F 1-\alpha$ & 0.36 & RPL24" & 0.54 \\
\hline 3 & RPL24 & 0.31 & $60 S r R N A$ & 0.33 & $U B C$ & 0.40 & ACT7 & 0.60 \\
\hline 4 & RPL25 & 0.40 & $U B C$ & 0.36 & $S A N D$ & 0.50 & $60 S r R N A$ & 0.68 \\
\hline 5 & $60 S$ rRNA & 0.43 & UBQ10 & 0.40 & TUA2 & 0.56 & $E F 1-\alpha$ & 0.77 \\
\hline 6 & GAPDH & 0.49 & GAPDH & 0.49 & $60 S r R N A$ & 0.62 & TUB3 & 0.81 \\
\hline 7 & $E F 1-\alpha$ & 0.54 & RPL25 & 0.54 & RPL25 & 0.98 & RPL25 & 0.85 \\
\hline 8 & TUB3 & 0.58 & $S A N D$ & 0.58 & ACT7 & 1.17 & UBQ10 & 0.93 \\
\hline 9 & CYP2 & 0.64 & TUB3 & 0.62 & RPL24 & 1.28 & GAPDH & 0.99 \\
\hline 10 & $P P 2 A$ & 0.69 & $E F 1-\alpha$ & 0.66 & GAPDH & 1.40 & $U B C$ & 1.04 \\
\hline 11 & $S A N D$ & 0.72 & CYP2 & 0.70 & UBQ10 & 1.50 & $F-b o x$ & 1.10 \\
\hline 12 & $U B C$ & 0.78 & $P P 2 A$ & 0.76 & $P P 2 A$ & 1.63 & CYP2 & 1.15 \\
\hline 13 & TUA2 & 0.83 & TUA2 & 0.84 & CYP2 & 1.75 & $S A N D$ & 1.21 \\
\hline 14 & $F-b o x$ & 0.88 & $F-b o x$ & 0.94 & $F-b o x$ & 1.88 & $P P 2 A$ & 1.28 \\
\hline
\end{tabular}

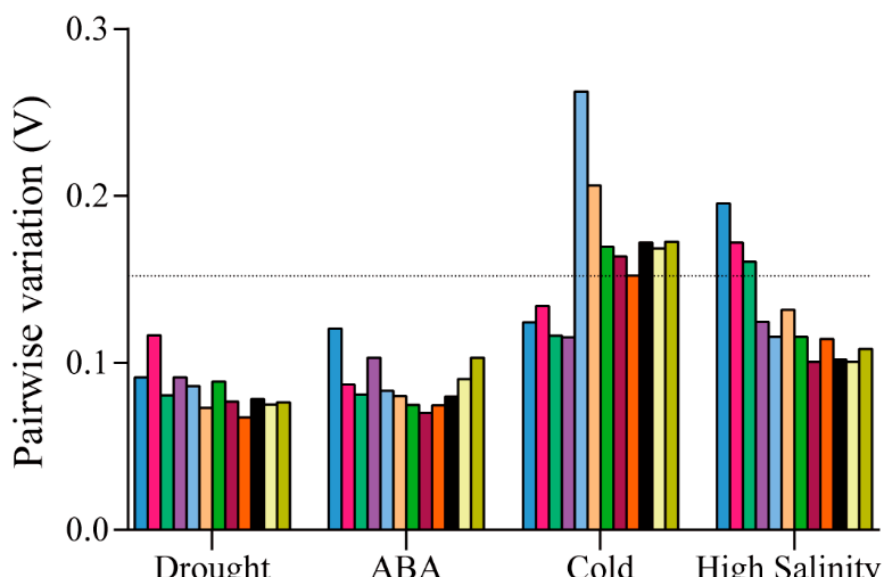

\begin{tabular}{|l|c|c|c|c|}
\multicolumn{1}{c}{} & Drought & \multicolumn{1}{c}{ ABA } & Cold & High Salinity \\
$\square \mathrm{V} 2 / 3$ & 0.0913 & 0.1207 & 0.1243 & 0.1957 \\
\hline$\square \mathrm{V} 3 / 4$ & 0.1165 & 0.0872 & 0.1342 & 0.1722 \\
\hline$\square \mathrm{V} 4 / 5$ & 0.0806 & 0.0810 & 0.1164 & 0.1605 \\
\hline$\square \mathrm{V} 5 / 6$ & 0.0914 & 0.1031 & 0.1153 & 0.1246 \\
\hline$\square \mathrm{V} 6 / 7$ & 0.0861 & 0.0835 & 0.2627 & 0.1155 \\
\hline$\square \mathrm{V} 7 / 8$ & 0.0731 & 0.0800 & 0.2063 & 0.1320 \\
\hline$\square \mathrm{V} 8 / 9$ & 0.0888 & 0.0748 & 0.1696 & 0.1156 \\
\hline$\square \mathrm{V} 9 / 10$ & 0.0769 & 0.0702 & 0.1638 & 0.1007 \\
\hline$\square \mathrm{V} 10 / 11$ & 0.0673 & 0.0747 & 0.1524 & 0.1144 \\
\hline$\square \mathrm{V} 11 / 12$ & 0.0784 & 0.0798 & 0.1722 & 0.1021 \\
\hline$\square \mathrm{V} 12 / 13$ & 0.0751 & 0.0904 & 0.1685 & 0.1006 \\
\hline$\square \mathrm{V} 13 / 14$ & 0.0764 & 0.1032 & 0.1727 & 0.1083 \\
\hline
\end{tabular}

Figure 3. Pairwise variation $(\mathrm{Vn} / \mathrm{Vn}+1)$ values of the fourteen experimental subsets calculated using geNorm. The cut-off value to determine the optimal number of RGs for qRT-PCR normalization is 0.15. 


\subsubsection{NormFinder Analysis}

The NormFinder program analyzes the stability of candidate RG expression based on the results of variance analysis and ranks the genes according to their stability [22]. As shown in Table 3, UBQ10 was the most stable candidate RG under drought, similar to the results of geNorm. But unlike the results of geNorm, UBQ10 was also ranked first in cold stress and ABA treatment. However, TUB3 (ranked first by geNorm) in cold stress and RPL24 and ACT7 (ranked first by geNorm) in ABA treatment had stabilities similar to that of $U B Q 10$, a result that differed from the geNorm analysis. For high salinity, $60 S$ rRNA was the most stable RG, which is again different from the result of the geNorm analysis.

Table 3. Expression stability of candidate reference genes calculated by NormFinder.

\begin{tabular}{|c|c|c|c|c|c|c|c|c|}
\hline \multirow{2}{*}{ Rank } & \multicolumn{2}{|c|}{ Drought } & \multicolumn{2}{|l|}{ ABA } & \multicolumn{2}{|l|}{ Cold } & \multicolumn{2}{|c|}{ High Salinity } \\
\hline & Gene Name & SV $^{1}$ & Gene Name & SV & Gene Name & SV & Gene Name & SV \\
\hline 1 & UBQ10 & 0.08 & UBQ10 & 0.05 & UBQ10 & 0.12 & $60 S$ rRNA & 0.15 \\
\hline 2 & ACT7 & 0.10 & RPL24 & 0.12 & TUB3 & 0.14 & RPL25 & 0.17 \\
\hline 3 & RPL24 & 0.10 & ACT7 & 0.12 & $S A N D$ & 0.16 & UBQ10 & 0.17 \\
\hline 4 & $G A P D H$ & 0.19 & $60 S r R N A$ & 0.13 & $U B C$ & 0.17 & ACT7 & 0.19 \\
\hline 5 & $60 S$ rRNA & 0.19 & $U B C$ & 0.17 & $E F 1-\alpha$ & 0.18 & RPL24 & 0.22 \\
\hline 6 & TUB3 & 0.20 & $S A N D$ & 0.19 & TUA2 & 0.20 & $U B C$ & 0.23 \\
\hline 7 & $E F 1-\alpha$ & 0.20 & TUB3 & 0.20 & $60 S$ rRNA & 0.21 & $E F 1-\alpha$ & 0.25 \\
\hline 8 & RPL25 & 0.22 & $E F 1-\alpha$ & 0.20 & GAPDH & 0.24 & TUB3 & 0.25 \\
\hline 9 & TUA2 & 0.23 & GAPDH & 0.23 & RPL25 & 0.24 & $S A N D$ & 0.28 \\
\hline 10 & CYP2 & 0.24 & RPL25 & 0.25 & RPL24 & 0.26 & TUA2 & 0.28 \\
\hline 11 & $U B C$ & 0.25 & TUA2 & 0.25 & ACT7 & 0.27 & GAPDH & 0.31 \\
\hline 12 & $F-b o x$ & 0.26 & CYP2 & 0.28 & $F-b o x$ & 0.34 & CYP2 & 0.32 \\
\hline 13 & SAND & 0.27 & $P P 2 A$ & 0.33 & $P P 2 A$ & 0.35 & $F-b o x$ & 0.32 \\
\hline 14 & $P P 2 A$ & 0.28 & $F-b o x$ & 0.43 & CYP2 & 0.40 & $P P 2 A$ & 0.39 \\
\hline
\end{tabular}

\subsubsection{BestKeeper Analysis}

BestKeeper assesses the stability of RGs by calculating the standard deviation (SD) and coefficient of variation $(\mathrm{CV})$ of the $\mathrm{Ct}$ values. An RG with an $\mathrm{SD}$ of less than 1.0 is considered to be stably expressed. The $C V$ decreases with the $S D$, indicating that the RG is more stable $[23,26]$. As shown in Table 4, UBQ10 was the most stable RG with the lowest SD and CV values under drought, high salinity, cold stress, and ABA treatment. Additionally, the SD and CV values of twelve candidate genes were less than 1.0 under drought stress, and only a few genes had SD and CV values greater than 1.0 under salinity stress and ABA treatment, indicating that the expression of most candidate RGs was relatively stable. 
Table 4. Expression stability of candidate reference genes calculated by BestKeeper.

\begin{tabular}{|c|c|c|c|c|c|c|c|c|c|c|c|c|}
\hline \multirow{2}{*}{ Rank } & \multicolumn{3}{|c|}{ Drought } & \multicolumn{3}{|c|}{ ABA } & \multicolumn{3}{|c|}{ Cold } & \multicolumn{3}{|c|}{ High Salinity } \\
\hline & Gene Name & $\mathrm{SD}^{1}$ & $\mathrm{CV}^{2}$ & Gene Name & SD & $\mathrm{CV}$ & Gene Name & SD & $\mathrm{CV}$ & Gene Name & SD & $\mathrm{CV}$ \\
\hline 1 & UBQ10 & 0.21 & 1.28 & $U B Q 10$ & 0.28 & 1.75 & $U B Q 10$ & 0.30 & 1.86 & UBQ10 & 0.39 & 2.49 \\
\hline 2 & GAPDH & 0.34 & 1.65 & SAND & 0.41 & 1.55 & $S A N D$ & 0.70 & 2.42 & $U B C$ & 0.42 & 2.26 \\
\hline 3 & RPL24 & 0.45 & 1.85 & CYP2 & 0.42 & 1.80 & GAPDH & 0.79 & 3.30 & GAPDH & 0.49 & 2.36 \\
\hline 4 & RPL25 & 0.53 & 2.39 & $F-b o x$ & 0.50 & 2.10 & CYP2 & 0.94 & 3.56 & F-box & 0.55 & 2.33 \\
\hline 5 & $60 S$ rRNA & 0.56 & 2.61 & ACT7 & 0.55 & 2.85 & $F-b o x$ & 1.26 & 4.46 & SAND & 0.58 & 2.22 \\
\hline 6 & $U B C$ & 0.59 & 2.93 & GAPDH & 0.55 & 2.56 & $P P 2 A$ & 1.16 & 5.08 & CYP2 & 0.58 & 2.50 \\
\hline 7 & ACT7 & 0.60 & 2.99 & RPL24 & 0.55 & 2.35 & $60 S$ rRNA & 1.27 & 5.68 & $E F 1-\alpha$ & 0.83 & 4.58 \\
\hline 8 & $P P 2 A$ & 0.63 & 3.63 & $60 S$ rRNA & 0.62 & 3.04 & TUB3 & 1.47 & 6.23 & $60 S$ rRNA & 0.84 & 4.17 \\
\hline 9 & $E F 1-\alpha$ & 0.64 & 3.30 & RPL25 & 0.74 & 3.52 & RPL24 & 1.75 & 6.71 & RPL24 & 0.92 & 3.80 \\
\hline 10 & SAND & 0.66 & 2.45 & $U B C$ & 0.76 & 3.96 & $U B C$ & 1.41 & 6.77 & $P P 2 A$ & 0.93 & 5.28 \\
\hline 11 & TUB3 & 0.68 & 3.02 & $E F 1-\alpha$ & 0.89 & 4.86 & $E F 1-\alpha$ & 1.62 & 7.67 & ACT7 & 0.94 & 4.78 \\
\hline 12 & TUA2 & 0.97 & 4.63 & TUB3 & 0.93 & 4.21 & TUA2 & 1.66 & 7.73 & TUA2 & 1.05 & 5.41 \\
\hline 13 & CYP2 & 1.01 & 4.55 & TUA2 & 1.52 & 7.49 & RPL25 & 1.97 & 8.34 & TUB3 & 1.06 & 4.89 \\
\hline 14 & F-box & 1.27 & 5.63 & $P P 2 A$ & 1.58 & 8.42 & ACT7 & 2.01 & 9.16 & RPL25 & 1.08 & 5.07 \\
\hline
\end{tabular}

\subsection{Comprehensive Stability Analysis of the Reference Genes}

The final comprehensive RG ranking is shown in Table 5 and Figure 4, based on the results from geNorm, NormFinder, and BestKeeper. UBQ10 and RPL24 were the most stable RGs under drought stress and ABA treatment, UBQ10 plus TUB3 was the best combination under cold stress, and UBQ10 plus $60 S$ rRNA was the best combination under high salinity stress. UBQ10 was the most stable RG under all experimental conditions.
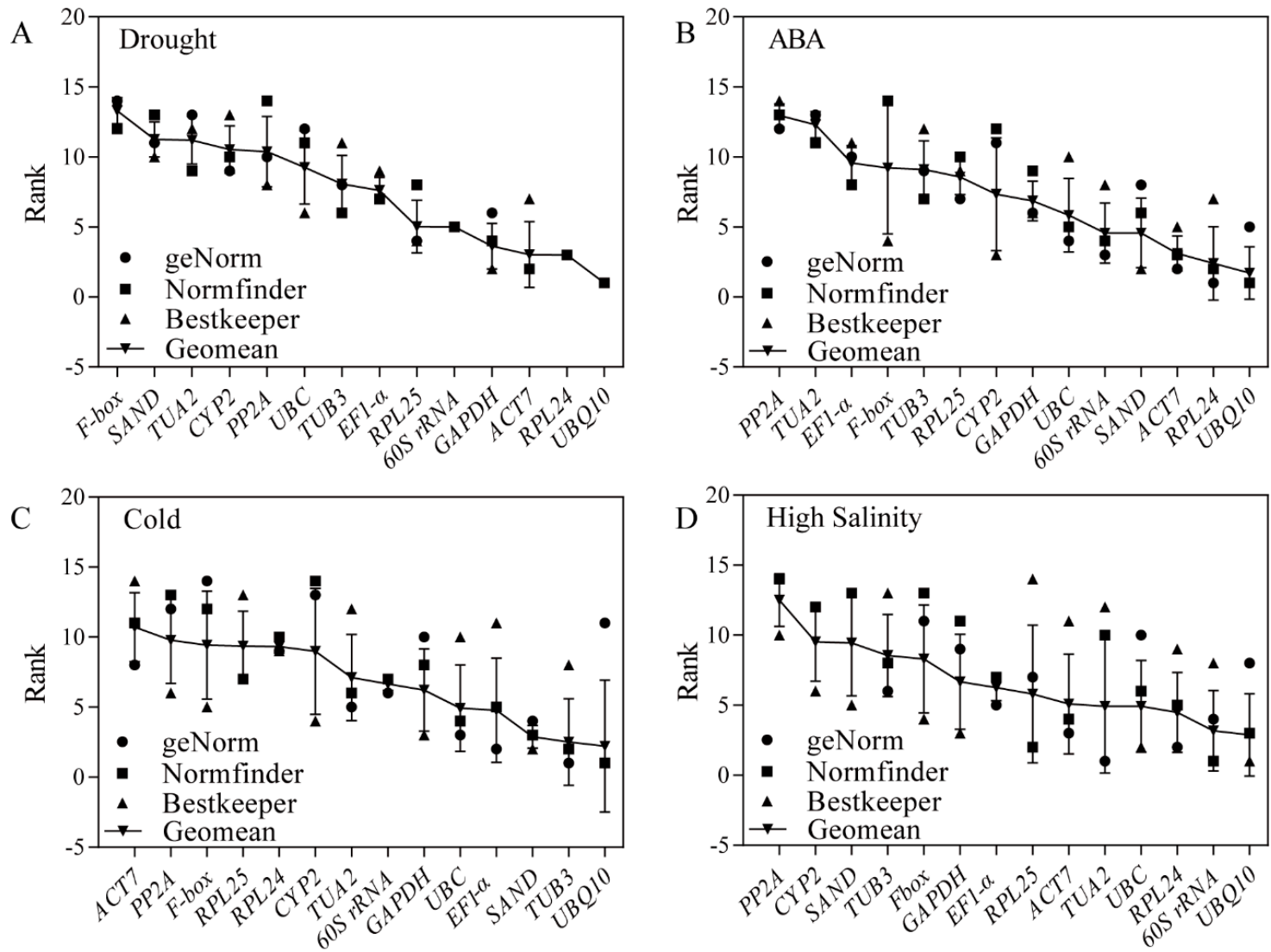

Figure 4. Comprehensive ranking of the fourteen RGs across all stresses and ABA treatment calculated as the geometric mean (Geomean) of three types of ranking (geNorm, NormFinder, and BestKeeper) for each sample group. (A) Drought stress, (B) ABA treatment, (C) cold stress, and (D) high salinity stress. 
Table 5. Expression stability ranking of the 14 candidate reference genes.

\begin{tabular}{|c|c|c|c|c|c|c|c|c|c|c|c|c|c|c|}
\hline Method & 1 & 2 & 3 & 4 & 5 & 6 & 7 & 8 & 9 & 10 & 11 & 12 & 13 & 14 \\
\hline \multicolumn{15}{|c|}{ A. Ranking order under drought stress } \\
\hline geNorm & UBQ10 & ACT7 & RPL24 & RPL25 & $60 S$ rRNA & GAPDH & $E F 1-\alpha$ & TUB3 & CYP2 & PP2A & SAND & $U B C$ & TUA2 & F-box \\
\hline NormFinder & UBQ10 & ACT7 & RPL24 & GAPDH & $60 S$ rRNA & TUB3 & $E F 1-\alpha$ & RPL25 & TUA2 & CYP2 & $U B C$ & $F-b o x$ & SAND & $P P 2 A$ \\
\hline BestKeeper & UBQ10 & GAPDH & RPL24 & RPL25 & $60 S$ rRNA & $U B C$ & ACT7 & $P P 2 A$ & $E F 1-\alpha$ & SAND & TUB3 & TUA2 & CYP2 & F-box \\
\hline $\begin{array}{l}\text { Comprehensive } \\
\text { Ranking }\end{array}$ & $U B Q 10$ & RPL24 & $A C T 7$ & GAPDH & $60 S r R N A$ & RPL25 & $E F 1-\alpha$ & TUB3 & $U B C$ & $P P 2 A$ & CYP2 & TUA2 & SAND & F-box \\
\hline \multicolumn{15}{|c|}{ B. Ranking order under ABA treatment } \\
\hline geNorm & RPL24 & ACT7 & $60 S$ rRNA & $U B C$ & $U B Q 10$ & GAPDH & RPL25 & SAND & TUB3 & $E F 1-\alpha$ & CYP2 & $P P 2 A$ & TUA2 & F-box \\
\hline NormFinder & UBQ10 & RPL24 & ACT7 & 60S rRNA & $U B C$ & SAND & TUB3 & EF1- $\alpha$ & GAPDH & RPL25 & TUA2 & CYP2 & $P P 2 A$ & F-box \\
\hline BestKeeper & UBQ 10 & $S A N D$ & CYP2 & $F-b o x$ & ACT7 & GAPDH & RPL24 & $60 S$ rRNA & RPL25 & $U B C$ & $E F 1-\alpha$ & ТUВ3 & TUA2 & $P P 2 A$ \\
\hline $\begin{array}{l}\text { Comprehensive } \\
\text { Ranking }\end{array}$ & UBQ10 & RPL24 & ACT7 & $60 S$ rRNA & $S A N D$ & $U B C$ & GAPDH & CYP2 & RPL25 & ТUВ3 & F-box & $E F 1-\alpha$ & TUA2 & $P P 2 A$ \\
\hline \multicolumn{15}{|c|}{ C. Ranking order under cold stress } \\
\hline geNorm & TUB3 & $E F 1-\alpha$ & $U B C$ & $S A N D$ & TUA2 & $60 S$ rRNA & RPL25 & ACT7 & RPL24 & GAPDH & UBQ10 & $P P 2 A$ & CYP2 & $F-b o x$ \\
\hline NormFinder & $U B Q 10$ & TUВ3 & SAND & $U B C$ & $E F 1-\alpha$ & TUA2 & $60 S$ rRNA & GAPDH & RPL25 & RPL24 & $\tilde{A C T 7}$ & $F-b o x$ & $P P 2 A$ & CYP2 \\
\hline BestKeeper & UBQ10 & $S A N D$ & GAPDH & CYP2 & $F-b o x$ & $P P 2 A$ & $60 S$ rRNA & TUВ3 & RPL24 & $U B C$ & $E F 1-\alpha$ & TUA2 & RPL25 & ACT7 \\
\hline $\begin{array}{l}\text { Comprehensive } \\
\text { Ranking }\end{array}$ & UBQ10 & TUB3 & $S A N D$ & $E F 1-\alpha$ & $U B C$ & GAPDH & $60 S$ rRNA & TUA2 & CYP2 & RPL24 & RPL25 & F-box & $P P 2 A$ & ACT7 \\
\hline \multicolumn{15}{|c|}{ D. Ranking order under high salinity stress } \\
\hline geNorm & TUA2 & RPL24" & ACT7 & $60 S$ rRNA & $E F 1-\alpha$ & ТUВ3 & RPL25 & UBQ10 & GAPDH & $U B C$ & F-box & CYP2 & SAND & $P P 2 A$ \\
\hline NormFinder & $60 S$ rRNA & RPL25 & UBQ10 & ACT7 & RPL24 & $U B C$ & $E F 1-\alpha$ & TUB3 & SAND & TUA2 & GAPDH & CYP2 & $F-b o x$ & $P P 2 A$ \\
\hline BestKeeper & UBQ10 & $U B C$ & $\widehat{G A P D H}$ & F-box & $S A N D$ & CYP2 & $E F 1-\alpha$ & $60 S$ rRNA & RPL24 & $P P 2 A$ & $A C T 7$ & TUA2 & TUB3 & RPL25 \\
\hline $\begin{array}{l}\text { Comprehensive } \\
\text { Ranking }\end{array}$ & $U B Q 10$ & $60 S$ rRNA & RPL24" & TUA2 & $U B C$ & ACT7 & RPL25 & $E F 1-\alpha$ & GAPDH & F-box & TUB3 & SAND & CYP2 & $P P 2 A$ \\
\hline
\end{tabular}




\subsection{Reference Gene Validation}

To verify the accuracy of the stable expression of the RGs, two marker genes (PuP5CS2 and PuGI) were used as positive controls in roots and leaves under drought, high salinity, cold stress, and ABA treatment (Figures 5 and 6). P5CS2 is a regulatory enzyme in proline biosynthesis and plays a crucial role in abiotic stress resistance and tolerance [29-32]. GI encodes a nuclear-localized protein that regulates both freezing tolerance and various development processes such as photoperiod-mediated flowering [33]. We selected two RGs based on the comprehensive ranking results for each stress and used them to normalize the PuP5CS2 and PuGI expression data. The selected RGs were UBQ10 and RPL24 for drought, ABA, UBQ10, and TUB3 for cold stress, and UBQ10 and 60S rRNA for high salinity. When the two optimal RGs were used for normalization, the expression levels of PuP5CS2 and PuGI differed among treatments (Figures 5 and 6). Under drought stress, PuP5CS2 was induced in roots and reached a maximum expression value at $48 \mathrm{~h}$ (Figure 4). PuP5CS2 was also upregulated by ABA treatment and reached a maximum value at $24 \mathrm{~h}$ (Figure 4). Under cold stress, PuP5CS2 was upregulated in both roots and leaves and was significantly induced at $48 \mathrm{~h}$ and $72 \mathrm{~h}$. PuGI was significantly upregulated ( $>20$ fold) in leaves under cold stress, and its expression also responded to drought and high salinity (Figure 5). Similar expression patterns were observed when we used the two single appropriate genes as RGs. However, the expression patterns of PuP5CS2 and PuGI showed significant fluctuations when the least stable gene, $P P 2 A$, was selected as the RG, and their expression patterns were not consistent with those observed when more appropriate RGs were used in specific experimental conditions (Figures 5 and 6).
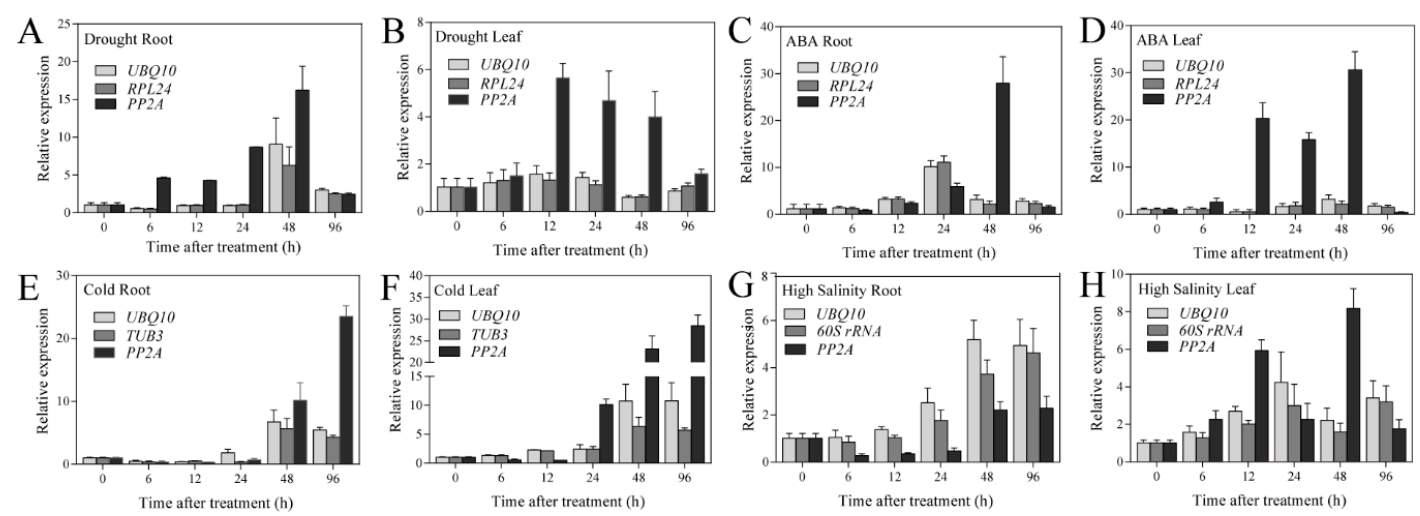

Figure 5. Relative expression levels of $P u P 5 C S 2$ under different experimental conditions normalized by the top two stable genes and an unstable gene. (A,B) Drought stress; (C,D) ABA treatment; (E,F) cold stress; and $(\mathbf{G}, \mathbf{H})$ high salinity stress.
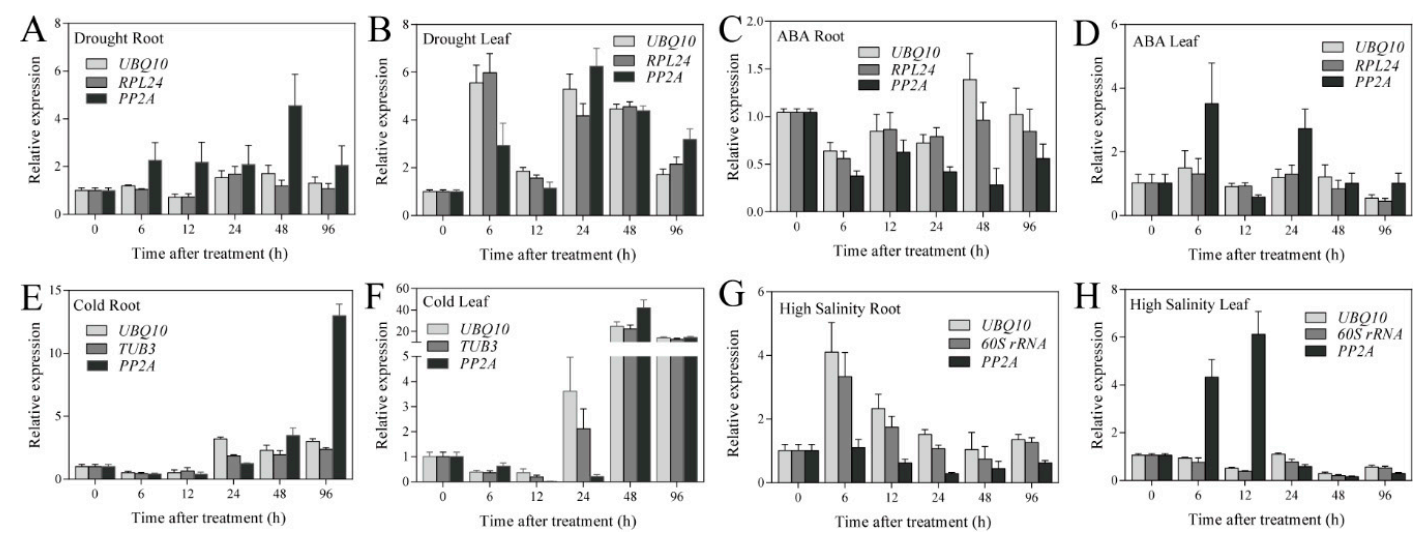

Figure 6. Relative expression levels of $P u G I$ under different experimental conditions normalized by the top two stable genes and an unstable gene. (A,B) Drought stress; (C,D) ABA treatment; (E,F) cold stress; and $(\mathbf{G}, \mathbf{H})$ high salinity stress. 


\section{Discussion}

To improve forest productivity and maintain the forest's economic benefits, it is necessary to identify stably-expressed RGs for use in qRT-PCR normalization when studying transcriptional regulatory pathways and the functions of key genes in P. ussuriensis. Abiotic stresses such as drought, high salinity, and cold temperatures are the main environmental factors that limit forest growth. ABA is a key signaling molecule during abiotic stress response and has particularly important biological functions in the response to drought [34], high salinity [35], and low temperature [36]. Under these stresses, increased levels of endogenous ABA can upregulate many stress-related genes in an ABA-dependent manner [37]. Numerous studies have identified and validated RGs in rice [38], maize [39], soybean [40,41], and carrot [42] under abiotic stress. However, there are currently no reports of RGs that are universally and stably expressed under abiotic stress in P. ussuriensis. The purpose of our study was therefore to select suitable RGs for qRT-PCR in P. ussuriensis under various abiotic stresses.

Fourteen candidate RGs were selected, including traditional housekeeping genes $(A C T 7, U B Q 10$, GAPDH, TUA2, TUB3, and EF1- $\alpha$ ) and widely-used RGs (60S rRNA, SAND, CYP2, PP2A, F-box, RPL24, $R P L 25$, and $U B C)$. The suitability of these candidate RGs was then evaluated using three algorithms including geNorm, NormFinder, and BestKeeper. Under drought, all algorithms ranked UBQ10 as having the highest stability. However, in other treatments, differences were observed in gene stability values and relative rankings generated by the different algorithms. For example, ACT7 was ranked second by geNorm and NormFinder, but it was ranked in the middle of the 14 candidate RGs by BestKeeper. Under ABA treatment, RPL24 and ACT7 were ranked among the top three most stable genes by geNorm and NormFinder, but they were ranked in intermediate positions by BestKeeper. These differences may be due to the different algorithms used to calculate stability. Previous studies have reported similar differences in stability ranking [43]. In general, the use of more than two algorithms is recommended to screen for stably-expressed RGs [21].

In our study, we calculated a comprehensive ranking of candidate genes based on the geometric mean of the rank results from three algorithms in each experimental condition. UBQ10 ranked as the most stable RG under all stresses and ABA treatment in P. ussuriensis. Our results were consistent with the stable expression of $U B Q$ reported in Platycladus orientalis under $\mathrm{NaCl}$ and ABA treatments [44], white clover leaves and stolons under water-limited and well-watered conditions [45], Brachypodium distachyon in different tissues and under various hormone treatments [46] and $A$. thaliana green siliques and seeds under hormone treatment [47]. However, UBQ showed less-stable expression in salt-stressed Suaeda aralocaspica seeds [48] and in different developmental stages and photoperiodic treatments in soybean [13]. UBQ, which is primarily involved in proteolysis in the ubiquitin-proteasome system, appears to be regulated differently in different plant species and cell types and in response to different experimental conditions [46,49]. Therefore, although UBQ10 was a universally reliable RG in our study, further verification is needed to determine its suitability for use as an RG under other experimental conditions.

According to the comprehensive ranking, RPL24 emerged as a relatively-stable choice for drought and high salinity stresses, and ABA treatment. RPL24, named as 605 ribosomal protein L24, is one of several large ribosomal subunit proteins widely used as an RG in many studies. For example, $60 S$ rRNA was stably expressed among different developmental stages in Panax ginseng [50]. Others include RPL30, which has been used as an RG in roots and shoots of soybean seedlings under cold stress and ABA treatment [40], and RPL2, which is stably expressed under nitrogen, cold, and light stress in tomato [8]. Ribosomal protein genes are also widely used as RGs in animals [51-53]. In our study, RPL25, which encodes a different large ribosomal subunit protein, was also evaluated. However, RPL25 was not an optimal RG under any condition in P. ussuriensis. In our study, the performances of RPL24 and 60S rRNA were within an acceptable range in all stresses and ABA treatments. Actin has been used extensively as a traditional HKG for normalization of gene expression data [54]. In our study, geNorm and NormFinder ranked ACT7 among the top four stable genes in roots and leaves 
under drought, high salinity, and ABA treatment. As noted previously, the expression of ACT7 is relatively stable under ultraviolet treatment in rice, drought, high salinity, and cold stress in common bean, and high salinity and cold stress in peanut $[11,55,56]$. However, its expression varies in pollen, seeds, and roots in A. thaliana [47]. Therefore, the expression of traditional housekeeping genes is not always stable under all experimental conditions.

SAND and TUB3 were two of the top three stable genes under cold stress. Han et al. [57] and Reid et al. [58] reported that $S A N D$ was a suitable RG for gene expression analysis in iron-deficient $A$. thaliana and in developing grape berry tissues. However, $S A N D$ has not been reported previously as a stable RG under low-temperature stress in any species. Similar to our results, previous studies have reported that TUB was stably expressed as an RG in various developmental stages of soybean [13], different tissues of poplar [59], and the barks of Populus yunnanensis cuttings [60]. The expression of TUB was relatively stable in leaves from powdery mildew-infected wheat [61] and in P. orientalis seedlings under cold, heat, salinity, PEG, and ABA treatment [44]. TUB was also reported as a suitable RG in all tissues (root, stem, and leaf) under multiple abiotic stress (cold, heat, salinity, and drought), and hormone treatments (ABA, SA, ET, and GA3) in maize [62]. These results suggest that the expression of the same RG varies among organs, developmental stages, and environmental conditions.

We analyzed the expression levels of two target genes (PuP5CS2 and PuGI) to validate the applicability and stability of suitable, high-ranking RGs. Consistent results were obtained by comparing the top two high-ranking RGs in roots and leaves under drought, high salinity, cold stress, and ABA treatment. The expression of PuP5CS2 was significantly induced in roots under drought, high salinity, and ABA treatment. Similar expression patterns of SbP5CS1 and SbP5CS2 under drought and high salinity were reported in sorghum [29]. In A. thaliana, AtP5CS1 responded to ABA and salt stress through controlling proline accumulation [63]. The expression of $P u G I$ was upregulated significantly in leaves during cold stress but not following ABA treatment, which is consistent with the behavior of GI in A. thaliana. In addition, GI was not induced by drought stress or ABA treatment in A. thaliana, but $P u G I$ was upregulated under drought stress and ABA treatment in our study. This result may be because different species and RGs were used in the experiments.

We compared the results of $P u P 5 C S 2$ and $P u G I$ expression analysis performed using appropriate and inappropriate RGs. When the appropriate RGs were used for normalization, the expression patterns of PuP5CS2 and PuGI were similar, but some differences still emerged. As previous studies have noted, more RGs are often required to correct for non-specific experimental variation and small differences in qRT-PCR conditions [27]. Nevertheless, when the expression data for PuP5CS2 and PuGI were normalized using inappropriate RGs, there were significant biases. These results indicate that the RGs screened in this study were reliable.

In summary, we evaluated and validated stable RGs in P. ussuriensis under abiotic stresses (drought, high salinity, and cold stress) and following treatment with the drought-related hormone ABA. The appropriate RGs for the qRT-PCR normalization of target gene expression data were UBQ10 and RPL24 for drought and ABA treatment, UBQ10 and TUB3 for cold stress, and UBQ10 and 60S $r R N A$ for salinity stress. Suitable RGs differed among various stresses and treatments. However, $U B Q 10$ appeared to be the most reliable RG across all experimental conditions in this study.

\section{Conclusions}

We selected fourteen candidate RGs to validate their expression stability using three algorithms, namely geNorm, NormFinder, and BestKeeper during abiotic stress (drought, high salinity, and cold stress) and after the treatment with the drought-related hormone ABA in P. ussuriensis. The results of the three algorithms were analyzed using comprehensive ranking. We identified the most appropriate reference genes, which were UBQ10 and RPL24 for drought and ABA treatment, UBQ10 and TUB3 for cold stress, and UBQ10 and $60 S$ rRNA for high salinity. UBQ10 was the most stable reference gene for use as an internal control, whereas $P P 2 A$ expression was the least stable. Furthermore, the expression of two target genes (P5CS2 and GI) confirmed the importance of selecting appropriate RGs 
in gene expression studies. This study provides a guideline for molecular studies of gene expression in $P$. ussuriensis under various abiotic stresses and provides the foundation for genomic researches in woody species.

Supplementary Materials: The following are available online at http://www.mdpi.com/1999-4907/11/4/476/s1, Figure S1: Agarose gel electrophoresis of PCR products for each of the fourteen RGs and the two target genes; Figure S2: Dissociation curves of the qRT-PCR amplicons for 14 RGs.

Author Contributions: Conceptualization, M.W. and C.L.; formal analysis, M.W., Y.C. and M.Z.; funding acquisition, M.W. and C.L.; methodology, J.Y. and C.L.; project administration, J.Y.; resources, J.Y.; software, Y.C., M.Z., H.L. and X.Z.; writing-Original draft, M.W.; writing-Review and editing, M.W. and C.L. All authors have read and agreed to the published version of the manuscript.

Funding: This research was funded by the Fundamental Research Funds for the Central Universities of China (Grant No. 2572018AA14), the 111 Project (Grant No. B16010) and the National Natural Science Foundation of China (Grant No. 31670668, Grant No. 31971671).

Conflicts of Interest: The authors declare no conflict of interest.

\section{References}

1. Bogdanović, M.; Dragićević, M.; Tanić, N.T.; Todorović, S.; Mišić, D.; Živković, S.; Tissier, A.; Simonović, A. Reverse Transcription of $18 \mathrm{~S}$ rRNA with Poly(dT)18 and Other Homopolymers. Plant Mol. Boil. Rep. 2012, 31, 55-63. [CrossRef]

2. Liu, X.; Guan, H.; Song, M.; Fu, Y.; Han, X.; Lei, M.; Ren, J.; Guo, B.; He, W.; Wei, Y. Reference gene selection for qRT-PCR assays in Stellera chamaejasme subjected to abiotic stresses and hormone treatments based on transcriptome datasets. PeerJ 2018, 6, e4535. [CrossRef] [PubMed]

3. VanGuilder, H.D.; Vrana, K.E.; Freeman, W.M. Twenty-five years of quantitative PCR for gene expression analysis. Biotechniques 2008, 44, 619-626. [CrossRef] [PubMed]

4. Kozera, B.; Rapacz, M. Reference genes in real-time PCR. J. Appl. Genet. 2013, 54, 391-406. [CrossRef] [PubMed]

5. Huggett, J.; Dheda, K.; Bustin, S.; Zumla, A. Real-time RT-PCR normalisation; strategies and considerations. Genes Immun. 2005, 6, 279-284. [CrossRef] [PubMed]

6. Bustin, S.; Beaulieu, J.-F.; Huggett, J.; Jaggi, R.; Kibenge, F.S.; Olsvik, P.; Penning, L.; Toegel, S. MIQE précis: Practical implementation of minimum standard guidelines for fluorescence-based quantitative real-time PCR experiments. BMC Mol. Boil. 2010, 11, 74. [CrossRef]

7. Li, M.-Y.; Xiong, A.-S.; Wang, F.; Xiong, A.-S. Suitable Reference Genes for Accurate Gene Expression Analysis in Parsley (Petroselinum crispum) for Abiotic Stresses and Hormone Stimuli. Front. Plant Sci. 2016, 7, 1263. [CrossRef]

8. Løvdal, T.; Lillo, C. Reference gene selection for quantitative real-time PCR normalization in tomato subjected to nitrogen, cold, and light stress. Anal. Biochem. 2009, 387, 238-242. [CrossRef]

9. Jain, M.; Nijhawan, A.; Tyagi, A.K.; Khurana, J.P. Validation of housekeeping genes as internal control for studying gene expression in rice by quantitative real-time PCR. Biochem. Biophys. Res. Commun. 2006, 345, 646-651. [CrossRef]

10. Penfield, S.; Hall, A. A Role for Multiple Circadian Clock Genes in the Response to Signals That Break Seed Dormancy in Arabidopsis. Plant Cell 2009, 21, 1722-1732. [CrossRef]

11. Kim, B.-R.; Nam, H.-Y.; Kim, S.-U.; Kim, S.-I.; Chang, Y.-J. Normalization of reverse transcription quantitative-PCR with housekeeping genes in rice. Biotechnol. Lett. 2003, 25, 1869-1872. [CrossRef]

12. Xu, M.; Zhang, B.; Su, X.; Zhang, S.; Huang, M. Reference gene selection for quantitative real-time polymerase chain reaction in Populus. Anal. Biochem. 2011, 408, 337-339. [CrossRef]

13. Jian, B.; Liu, B.; Bi, Y.; Hou, W.; Wu, C.; Han, T. Validation of internal control for gene expression study in soybean by quantitative real-time PCR. BMC Mol. Boil. 2008, 9, 59. [CrossRef]

14. Jin, J.; Zhao, X.; Liu, H.; Wang, S.; Song, Z.; Ma, X.; Li, K. Preliminary study on genetic variation of growth traits and wood properties and superior clones selection of Populus ussuriensis Kom. iForest Biogeosci. For. 2019, 12, 459-466. [CrossRef]

15. Wei, M.; Xu, X.; Li, C. Identification and expression of CAMTA genes in Populus trichocarpa under biotic and abiotic stress. Sci. Rep. 2017, 7, 17910. [CrossRef] 
16. Zhao, H.; Zhao, X.; Li, M.; Jiang, Y.; Xu, J.; Jin, J.; Li, K. Ectopic expression of Limonium bicolor (Bag.) Kuntze DREB (LbDREB) results in enhanced salt stress tolerance of transgenic Populus ussuriensis Kom. Plant Cell Tissue Organ Cult. 2017, 132, 123-136. [CrossRef]

17. Zhang, H.; Yang, J.; Li, W.; Chen, Y.; Lu, H.; Zhao, S.; Li, D.; Wei, M.; Li, C. PuHSFA4a Enhances Tolerance to Excess Zinc by Regulating Reactive Oxygen Species Production and Root Development in Populus. Plant Physiol. 2019, 180, 2254-2271. [CrossRef]

18. Li, S.; Lin, Y.-C.; Wang, P.; Zhang, B.; Li, M.; Chen, S.; Shi, R.; Tunlaya-Anukit, S.; Liu, X.; Wang, Z.; et al. The AREB1 Transcription Factor Influences Histone Acetylation to Regulate Drought Responses and Tolerance in Populus trichocarpa. Plant Cell 2018, 31, 663-686. [CrossRef]

19. Wang, Z.; Liu, Q.; Wang, H.; Zhang, H.; Xu, X.; Li, C.; Yang, C. Comprehensive analysis of trihelix genes and their expression under biotic and abiotic stresses in Populus trichocarpa. Sci. Rep. 2016, 6, 36274. [CrossRef]

20. Liu, Q.; Wang, Z.; Xu, X.; Zhang, H.; Li, C. Genome-Wide Analysis of C2H2 Zinc-Finger Family Transcription Factors and Their Responses to Abiotic Stresses in Poplar (Populus trichocarpa). PLoS ONE 2015, 10, e0134753. [CrossRef]

21. Vandesompele, J.; De Preter, K.; Pattyn, F.; Poppe, B.; Van Roy, N.; De Paepe, A.; Speleman, F. Accurate normalization of real-time quantitative RT-PCR data by geometric averaging of multiple internal control genes. Genome Boil. 2002, 3, 7. [CrossRef]

22. Andersen, C.L.; Jensen, J.L.; Ørntoft, T.F. Normalization of Real-Time Quantitative Reverse Transcription-PCR Data: A Model-Based Variance Estimation Approach to Identify Genes Suited for Normalization, Applied to Bladder and Colon Cancer Data Sets. Cancer Res. 2004, 64, 5245-5250. [CrossRef] [PubMed]

23. Pfaffl, M.; Tichopad, A.; Prgomet, C.; Neuvians, T.P. Determination of stable housekeeping genes, differentially regulated target genes and sample integrity: BestKeeper-Excel-based tool using pair-wise correlations. Biotechnol. Lett. 2004, 26, 509-515. [CrossRef]

24. Jaakola, L.; Pirttilä, A.M.; Halonen, M.; Hohtola, A. Isolation of High Quality RNA from Bilberry (Vaccinium myrtillus L.) Fruit. Mol. Biotechnol. 2001, 19, 201-204. [CrossRef]

25. Livak, K.J.; Schmittgen, T.D. Analysis of relative gene expression data using real-time quantitative PCR and the 2(-Delta Delta C(T)) Method. Methods 2001, 25, 402-408. [CrossRef]

26. Dheda, K.; Huggett, J.; Chang, J.; Kim, L.; Bustin, S.; Johnson, M.; Rook, G.; Zumla, A. The implications of using an inappropriate reference gene for real-time reverse transcription PCR data normalization. Anal. Biochem. 2005, 344, 141-143. [CrossRef]

27. Bustin, S.; Benes, V.; Garson, J.A.; Hellemans, J.; Huggett, J.; Kubista, M.; Mueller, R.; Nolan, T.; Pfaffl, M.; Shipley, G.L.; et al. The MIQE Guidelines: Minimum Information for Publication of Quantitative Real-Time PCR Experiments. Clin. Chem. 2009, 55, 611-622. [CrossRef]

28. Joseph, J.T.; Poolakkalody, N.J.; Shah, J.M. Plant reference genes for development and stress response studies. J. Biosci. 2018, 43, 173-187. [CrossRef]

29. Su, M.; Li, X.-F.; Ma, X.-Y.; Peng, X.; Zhao, A.-G.; Cheng, L.; Chen, S.; Liu, G. Cloning two P5CS genes from bioenergy sorghum and their expression profiles under abiotic stresses and MeJA treatment. Plant Sci. 2011, 181, 652-659. [CrossRef]

30. Rai, A.N.; Suprasanna, P. Molecular evolution of plant P5CS gene involved in proline biosynthesis. Mol. Boil. Rep. 2013, 40, 6429-6435. [CrossRef]

31. Xia, Y.; Li, R.; Bai, G.; Siddique, K.H.M.; Varshney, R.K.; Baum, M.; Yan, G.; Guo, P. Genetic variations of HvP5CS1 and their association with drought tolerance related traits in barley (Hordeum vulgare L.). Sci. Rep. 2017, 7, 7870. [CrossRef] [PubMed]

32. Székelyg, G.; Ábrahám, E.; Cséplo, Á.; Rigó, G.; Zsigmond, L.; Csiszar, J.; Ayaydin, F.; Strizhov, N.; Jasik, J.; Schmelzer, E.; et al. DuplicatedP5CSgenes of Arabidopsis play distinct roles in stress regulation and developmental control of proline biosynthesis. Plant J. 2008, 53, 11-28. [CrossRef]

33. Cao, S.; Ye, M.; Jiang, S. Involvement of GIGANTEA gene in the regulation of the cold stress response in Arabidopsis. Plant Cell Rep. 2005, 24, 683-690. [CrossRef]

34. Du, Y.-L.; Wang, Z.-Y.; Fan, J.-W.; Turner, N.C.; He, J.; Wang, T.; Li, F.-M. Exogenous abscisic acid reduces water loss and improves antioxidant defence, desiccation tolerance and transpiration efficiency in two spring wheat cultivars subjected to a soil water deficit. Funct. Plant Boil. 2013, 40, 494. [CrossRef]

35. Khadri, M.; Tejera, N.; Lluch, C. Sodium chloride-ABA interaction in two common bean (Phaseolus vulgaris) cultivars differing in salinity tolerance. Environ. Exp. Bot. 2007, 60, 211-218. [CrossRef] 
36. Kobayashi, F.; Takumi, S.; Nakamura, C. Increased freezing tolerance in an ABA-hypersensitive mutant of common wheat. J. Plant Physiol. 2008, 165, 224-232. [CrossRef]

37. Nakashima, K.; Yamaguchi-Shinozaki, K. ABA signaling in stress-response and seed development. Plant Cell Rep. 2013, 32, 959-970. [CrossRef]

38. Maksup, S.; Supaibulwatana, K.; Selvaraj, G. High-quality reference genes for quantifying the transcriptional responses of Oryza sativa L. (ssp. indica and japonica) to abiotic stress conditions. Chin. Sci. Bull. 2013, 58, 1919-1930. [CrossRef]

39. Manoli, A.; Sturaro, A.; Trevisan, S.; Quaggiotti, S.; Nonis, A. Evaluation of candidate reference genes for qPCR in maize. J. Plant Physiol. 2012, 169, 807-815. [CrossRef]

40. Le, D.T.; Aldrich, D.L.; Valliyodan, B.; Watanabe, Y.; Van Ha, C.; Nishiyama, R.; Guttikonda, S.K.; Quach, T.N.; Gutierrez-Gonzalez, J.J.; Tran, L.S.P.; et al. Evaluation of candidate reference genes for normalization of quantitative RT-PCR in soybean tissues under various abiotic stress conditions. PLoS ONE 2012, 7, e0046487. [CrossRef]

41. Ma, S.; Niu, H.; Liu, C.; Zhang, J.; Hou, C.; Wang, N. Expression Stabilities of Candidate Reference Genes for RT-qPCR under Different Stress Conditions in Soybean. PLoS ONE 2013, 8, e75271. [CrossRef]

42. Tian, C.; Jiang, Q.; Wang, F.; Wang, G.-L.; Xiong, A.-S.; Xiong, A.-S. Selection of Suitable Reference Genes for qPCR Normalization under Abiotic Stresses and Hormone Stimuli in Carrot Leaves. PLoS ONE 2015, 10, e0117569. [CrossRef]

43. Wang, M.; Lu, S. Validation of Suitable Reference Genes for Quantitative Gene Expression Analysis in Panax ginseng. Front. Plant Sci. 2016, 6, 5245. [CrossRef]

44. Chang, E.; Shi, S.; Liu, J.; Cheng, T.; Xue, L.; Yang, X.; Yang, W.; Lan, Q.; Jiang, Z. Selection of Reference Genes for Quantitative Gene Expression Studies in Platycladus orientalis (Cupressaceae) Using Real-Time PCR. PLoS ONE 2012, 7, e33278. [CrossRef]

45. Narancio, R.; John, U.; Mason, J.; Spangenberg, G. Selection of optimal reference genes for quantitative RT-PCR transcript abundance analysis in white clover (Trifolium repens L.). Funct. Plant Boil. 2018, 45, 737-744. [CrossRef]

46. Hong, S.-Y.; Seo, P.J.; Yang, M.-S.; Liu, Z.; Park, C.-M. Exploring valid reference genes for gene expression studies in Brachypodium distachyon by real-time PCR. BMC Plant Boil. 2008, 8, 112. [CrossRef]

47. Czechowski, T.; Stitt, M.; Altmann, T.; Udvardi, M.K.; Scheible, W.-R. Genome-Wide Identification and Testing of Superior Reference Genes for Transcript Normalization in Arabidopsis. Plant Physiol. 2005, 139, 5-17. [CrossRef]

48. Cao, J.; Wang, L.; Lan, H. Validation of reference genes for quantitative RT-PCR normalization in Suaeda aralocaspica, an annual halophyte with heteromorphism and C4 pathway without Kranz anatomy. PeerJ 2016, 4, 1697. [CrossRef]

49. Gong, B.; Radulovic, M.; Figueiredo-Pereira, M.E.; Cardozo, C.P. The Ubiquitin-Proteasome System: Potential Therapeutic Targets for Alzheimer's Disease and Spinal Cord Injury. Front. Mol. Neurosci. 2016, 9, 3. [CrossRef]

50. Liu, J.; Wang, Q.; Sun, M.; Zhu, L.; Yang, M.; Zhao, Y. Selection of Reference Genes for Quantitative Real-Time PCR Normalization in Panax ginseng at Different Stages of Growth and in Different Organs. PLoS ONE 2014, 9, e112177. [CrossRef]

51. Zhang, X.; Ding, L.; Sandford, A.J. Selection of reference genes for gene expression studies in human neutrophils by real-time PCR. BMC Mol. Boil. 2005, 6, 4. [CrossRef]

52. Nygard, A.-B.; Jorgensen, C.B.; Cirera, S.; Fredholm, M. Selection of reference genes for gene expression studies in pig tissues using SYBR green qPCR. BMC Mol. Boil. 2007, 8, 67. [CrossRef]

53. Brinkhof, B.; Spee, B.; Rothuizen, J.; Penning, L.C. Development and evaluation of canine reference genes for accurate quantification of gene expression. Anal. Biochem. 2006, 356, 36-43. [CrossRef]

54. Sikand, K.; Singh, J.; Ebron, J.S.; Shukla, G. Housekeeping Gene Selection Advisory: Glyceraldehyde-3-Phosphate Dehydrogenase (GAPDH) and $\beta$-Actin Are Targets of miR-644a. PLoS ONE 2012, 7, e47510. [CrossRef] [PubMed]

55. Borges, A.; Tsai, S.M.; Caldas, D.G.G. Validation of reference genes for RT-qPCR normalization in common bean during biotic and abiotic stresses. Plant Cell Rep. 2011, 31, 827-838. [CrossRef] 
56. Chi, X.; Hu, R.; Yang, Q.; Zhang, X.; Pan, L.; Chen, N.; Chen, M.; Yang, Z.; Wang, T.; He, Y.; et al. Validation of reference genes for gene expression studies in peanut by quantitative real-time RT-PCR. Mol. Genet. Genom. 2011, 287, 167-176. [CrossRef]

57. Han, B.; Yang, Z.; Samma, M.K.; Wang, R.; Shen, W. Systematic validation of candidate reference genes for qRT-PCR normalization under iron deficiency in Arabidopsis. BioMetals 2013, 26, 403-413. [CrossRef]

58. Reid, K.E.; Olsson, N.; Schlosser, J.; Peng, F.; Lund, S.T. An optimized grapevine RNA isolation procedure and statistical determination of reference genes for real-time RT-PCR during berry development. BMC Plant Boil. 2006, 6, 27. [CrossRef]

59. Brunner, A.M.; Yakovlev, I.; Strauss, S.H. Validating internal controls for quantitative plant gene expression studies. BMC Plant Boil. 2004, 4, 14. [CrossRef]

60. Yun, T.; Li, J.; Zu, Y.; Zhou, A.; Zong, D.; Wang, S.; Li, D.; He, C. Selection of reference genes for RT-qPCR analysis in the bark of Populus yunnanensis cuttings. J. Environ. Boil. 2019, 40, 584-591. [CrossRef]

61. Scholtz, J.J.; Visser, B. Reference gene selection for qPCR gene expression analysis of rust-infected wheat. Physiol. Mol. Plant Pathol. 2013, 81, 22-25. [CrossRef]

62. Lin, Y.; Zhang, C.; Lan, H.; Gao, S.; Liu, H.; Liu, J.; Cao, M.; Pan, G.; Rong, T.; Zhang, S.-Z. Validation of Potential Reference Genes for qPCR in Maize across Abiotic Stresses, Hormone Treatments, and Tissue Types. PLoS ONE 2014, 9, e95445. [CrossRef] [PubMed]

63. Abrahám, E.; Rigó, G.; Székely, G.; Nagy, R.; Koncz, C.; Szabados, L. Light-dependent induction of proline biosynthesis by abscisic acid and salt stress is inhibited by brassinosteroid in Arabidopsis. Plant Mol. Boil. 2003, 51, 363-372. [CrossRef] [PubMed]

(C) 2020 by the authors. Licensee MDPI, Basel, Switzerland. This article is an open access article distributed under the terms and conditions of the Creative Commons Attribution (CC BY) license (http://creativecommons.org/licenses/by/4.0/). 